\title{
Led by the Spirit: Missional Communities and the Quakers on communal vocation discernment
}

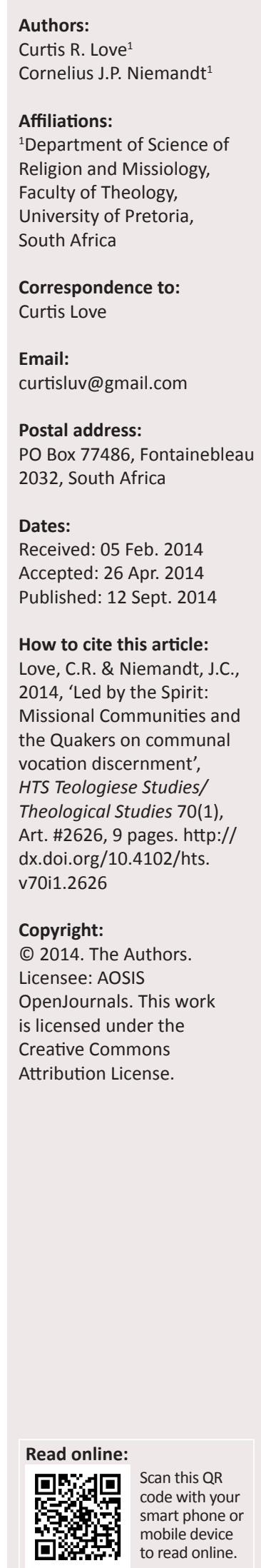

This article argues that the term missional is an expression of the global shift towards a theocentric (rather than ecclesiocentric) understanding of mission. A Missional Community is a concrete, local embodiment of this missional ecclesiology and it comes to be through discerning its particular and ongoing vocation in the cosmic missio Dei. It is for this reason that we argued that communal vocation discernment lies at the heart of the Missional Community's life and practice. This practice births, energises and renews the Missional Community in the wake of the boundary-breaking Spirit's work in the local neighbourhood or context. Because communal vocation discernment is central to Missional Communities it seemed prudent to ask which other communities or traditions see discernment as central to their life and practice. In Western Christianity, the Quakers stand out as a significant example of communal discernment as their normal way of making decisions. We sought to answer whether the Quaker practice of communal discernment, in the Meeting for Worship in which Business is Conducted, is a suitable model for communal vocation discernment in Missional Communities. We suggested that it was not suitable in so far as it did not express an explicit commitment to being grounded and connected to a place or neighbourhood as a prerequisite for discernment. We suggested that it was suitable in so far as it continually reminds the community that communal discernment is not simply about making decisions or finding your vocation but at its heart is an act of worship. This awareness in the Quakers is primarily achieved through naming communal discernment spaces as worship spaces and through the strategic use of silence. We also suggested that the Quaker commitment to unity and dissent creates space for belonging, agency and responsibility in the community and that this is something which Missional Communities would do well to appropriate in their own communal vocation discernment.

\section{Introduction}

Both Missional ${ }^{1}$ Communities and Quakers ${ }^{2}$ see discernment as the first act in the formation of the community of faith. For Missional Communities the first act of participation in a localised expression of the cosmic Mission of Christ is discernment (Kim 2009:34) and for Quakers this spirituality of discernment is understood as a 'waiting on the Lord' (Anderson n.d.:26). The primacy of discernment in these two communities means that an exploration of its practice will be both interesting and fruitful. In this article, we will be primarily concerned with what Missional Communities can learn from the Quaker tradition and practice of communal discernment. Quakers are both important and helpful to Missional Communities on this subject for at least two reasons. Firstly, according to Sheeran (1996:xiv), Quakers are 'the only modern Western community in which decision making achieves the group centred decisions of traditional societies'. The potential resonance between Quaker communal discernment and African communal decision making (beyond the scope of this article) makes the Quakers a desirable tradition to explore in the South African context. Hailey (2008:12) affirms this potential resonance when he argues that in traditional African societies 'every person at a meeting or gathering gets an equal chance to speak until some kind of an agreement or consensus is reached'. This group-centred approach to decision making is communicated through the Zulu word simunye - we are one, or unity in strength. Simunye naturally leads to the practice of forming a collective understanding (of issues and decisions affecting the community) through the sharing of ideas and perspectives between members of the community (Hailey 2008:12). Secondly, Quakers are appealing dialogue partners because they have used communal discernment as their ordinary decision making process for the past

Missional Communities are concrete expressions of a missional ecclesiology animated by the Spirit and a missional imagination that seek to faithfully discern the missio Dei in a specific time and place.

2.Also known as the Religious Society of Friends or just Friends; there is a distinction between 'programmed' and 'unprogrammed' Quakers. According to Anderson (n.d.:27), only about 15\% of Quakers globally are 'unprogrammed'. 'Unprogrammed' Quakers are those who above all else seek to 'wait quietly together before the Lord ... attending, discerning and minding the Divine Will' (Anderson n.d.:27). The rest of the Quakers in the 'pastoral and programmed tradition of Friends ... have evolved their own patterns and structures, within which a few minutes of quiet waiting or open worship (in which testimonies are often shared) punctuate an otherwise busied order of worship' (Anderson n.d.: 17). This study is following the tradition and practice of the Meeting for Worship in which Business is Conducted as practiced by 'unprogrammed' Quakers. 
three centuries' (Sheeran 1996:xiii). It would be fruitful for Missional Communities who count discernment as the heart of their life and practice (Niemandt 2012:2; Van Gelder \& Zscheile 2011:130) to engage a community with such a long and rich tradition of communal discernment.

Engagement with the Quaker practice of communal vocation discernment will be in the form of an appropriation (Downey 1997:129), which Downey (1997:129) describes as 'not just notional or theoretical but transformational ... in other words, when meanings, purposes and values are appropriated, i.e. understood "from the inside out" they transform'. This method seems most suitable as it allows us to look at the practice of communal discernment from 'the inside out' for meanings, purposes and values as a means of transforming the practice of communal vocation discernment in Missional Communities. In order to do this, we will need to traverse some terrain. We will begin by briefly tracing the emergence of 'missional' as a descriptor of a missional ecclesiology which will be followed by describing Missional Communities as a concrete, local expression of a missional ecclesiology. This will be followed by establishing the centrality of communal vocation discernment in the life of a Missional Community. This will then set the stage for us to consider the Quaker practice of communal discernment in order to see what can be distilled and appropriated into the life and practice of Missional Communities.

\section{The emergence of 'missional' as a missional ecclesiology}

As with most discussions about missional ecclesiology these days, we too must begin by acknowledging the significant global shift that has occurred within a part of Western Christianity's self-understanding of mission. This shift, which occurred in the last century (ed. Guder 1998:4), signals a move from an ecclesiocentric to a theocentric understanding of mission (Barret et al. 2004:ix-x; Bosch 1991:389; Guder 1998:4; Guder 2000:20; Hendriks 2007:105; Shenk 1995:38; see also Love 2013b). In this shift, a part of the Western Church has come to see that:

$[M]$ ission is not merely an activity of the church. Rather mission is the result of God's initiative, rooted in God's purposes to restore and heal creation. 'Mission' means 'sending' and it is the central biblical theme describing the purposes of God's action in human history. (Guder 1998:4)

In short, mission is 'derived from the very nature of God' (Bosch 1991:389; Guder 2000:20). In this last century certain parts of the Western Church (Niemandt 2012:1-9) have begun to discover that the missio is in fact the missio Dei. The three most succinct and often quoted 'foundational' articulations of this shift from an ecclesiocentric to a theocentric understanding of mission can be found in Newbigin's Mission Christ's Way (1987), Bosch's Transforming mission: Paradigm shifts in theology of mission (1991) and Guder's Missional Church: A vision for the sending of the Church in North America (1998). These authors are worth quoting in full (see also Love 2013b):

It is not that the church has a mission and the Spirit helps us in fulfilling it. It is rather that the Spirit is the active missionary, and the church (where it is faithful) is the place where the Spirit is enabled to complete the Spirit's work. (Newbigin 1987:20)

The classical doctrine of the missio Dei as God the father sending the Son, and God the Father and Son sending the Spirit was expanded to include yet another 'movement': Father, Son and Holy Spirit sending the Church into the world ... our mission has no life of its own, only in the hands of the sending God can it truly be called mission, not least the since the missionary initiative comes from God alone. (Bosch 1991:390; [authors' own emphasis])

The ecclesiocentric understanding of mission has been replaced during this century by a profoundly theocentric reconceptualization of Christian mission. We have come to see that mission is not merely an activity of the church. Rather, mission is the result of God's initiative, rooted in God's purposes to restore and heal creation. 'Mission' means sending, and it is the central biblical theme that describes the purpose of God's action in human history. (Guder 1998:4; [authors' own emphasis])

Central to these core articulations is the conviction that mission is to be located in the very nature of the sending God (Niemandt 2012:2), a radical break from the ecclesiocentric understanding of mission which has come to dominate the Western Church (see also Love 2013b). This theocentric understanding of mission has been enthusiastically and persuasively argued for by the Missional Church movement ${ }^{3}$ (Van Gelder \& Zscheile 2011:3). The Missional Church at its best, is aware that its emergence as a movement is built on a 'cluster of idea's which convey important biblical and theological commitments' (Van Gelder \& Zscheile 2011:3). This 'cluster of ideas' has shaped and serves as a resource for ongoing renewal and development in the movement. Van Gelder and Zscheile in their generative work The missional church in perspective: Mapping trends and shaping the conversation (2011) delineate six ideas which are recognised as formative in the Missional Church movement. These include Trinitarian missiology, The distinction between Church missions and mission, Mission Dei, Reign (Kingdom) of God, The church's missionary nature and a Missional hermeneutic (cf. Wright 2006).

A missional ecclesiology grounded in the missio Dei described above has gained some traction, in both popular and academic use, in the term 'missional' (Van Gelder 2007b:viii). McKinzie (2010:10) believes that the adoption of 'missional' as a descriptor was driven by 'all that we have learned in the twentieth century as we became more aware that the Christian movement was in fact a global reality, a "world missionary community"'. This more 'spacious' understanding of mission which grounds the 'identity and purpose of the church within God's mission, subordinate to and focused upon God's purpose' (Guder 2009:65) required

3.See Connor (2011:142-420) for an explanation of the Missional Church Movement and the role of the Gospel in Our Culture Network (GOCN). 
some new terminology and so, according to Guder, the term 'missional' was introduced; this introduction was:

[I]n order to foster this more radical way of thinking about the church and, more generally, of doing theology ... it was an attempt to unpack the operative assumption that 'the church is missionary in its very nature'. (p. 65)

Van Gelder and Zscheile (2011:49) affirm Guder's assessment of the use of term by arguing that missional is a term that is used to show the explicit connection between missiology and ecclesiology in a missional ecclesiology.

\section{Missional Communities as a concrete expression of a missional ecclessiology}

Thus far we have explored the theological and historical roots of a missional ecclesiology as well as the emergence of the term 'missional' as a descriptor of this comprehensive understanding of mission. Let us now turn to the concrete expression of this missional ecclesiology.

Christian communities that are missional express a missional ecclesiology and can be identified in the literature as Missional Communities (Hendriks 2007:1002), missional congregations (Zscheile 2012:3) or Missional Churches (Barrett et al. 2004:x; Macllvaine 2009:12). These differences in descriptions point to diverse faith-traditioned expressions of the same core imagination of a missional ecclesiology (Van Gelder \& Zscheile 2011:3) rather than any substantive underlying difference. According to this understanding of a missional ecclesiology, local communities of faith (Hendriks 2007:1002; Macllvaine 2009:10; Niemandt 2010:411) comprising authentic communal structures (Niemandt 2010:3) are the basic building blocks of the church (Hendriks 2007:1002). The institutional church '... might be important, but the missional church is a local church' (Niemandt 2012:7). It is a community that has been '... called, gathered and equipped by the Spirit and sent to participate in God's mission by bringing the Gospel of God's love and new life' (Niemandt 2012:2) to a particular place and time. This means that a missional ecclesiology sees the church existing '... first and foremost on the level of a local community' (Niemandt 2012:7), where it is to be a 'sign', 'foretaste', 'agent', and 'instrument' of the reign of God (Guder 1998:97-102). Recent ecumenical gatherings echo this shift towards the local nature of missional engagement (Balia \& Kim 2010:118). The World Communion of Reformed Churches (WCRC) states that 'the primary place for missional engagement is the local community in which Christians live' (WCRC 2010:165).

For the purpose of this study and clearer communication we shall refer to these communities which form the basic building blocks of the church as Missional Communities. This is done with sensitivity to traditions that might refer to themselves as missional congregations or Missional Churches.

Missional Communities are not about strategies or models but rather about 'working with the [biblical] currents that shape our imagination of what God is doing in the world' (Roxburgh \& Boren 2009:37-39). Van Gelder and Zscheile (2011:149) articulate what animates a Missional Community when they describe it as 'a habit of heart and mind, a posture of openness and discernment, and a faithful attentiveness to the Spirit's presence and to the world that God so loves'. If this is what animates a Missional Community, it is not difficult to see why a comprehensive definition would be both difficult and indeed undesirable. These authors advocate for understanding missional with descriptors like missional imagination (Van Gelder \& Zscheile 2011:147), journey (Van Gelder \& Zscheile 2011:92) or God's dynamic relationship with the world (Van Gelder \& Zscheile 2011:92; see also Love 2013b).

In an effort to clear some space and illuminate the co-opted (mis)use and (mis)understanding of what a Missional Church or community is Roxburgh and Boren (2009:33) define Missional Church in the negative. Part of what Roxburgh and Boren achieve by defining Missional Church in the negative is to show that any expression of the church is (or at least should be) relative to the ongoing and unfolding Mission of God. It is also clear that Roxburgh and Boren (2009:45) agree with Van Gelder and Zscheile that there is no model for what a Missional Community looks like as it manifests itself differently depending on social and historical location, it is 'the essence that pervades all the church is'. An appropriate and localised expression emerges from the local Missional Community's participation in the Triune God's movement in that particular part of the world. Understanding the relative nature of the church is a critical element in the renewal of the church in dynamic and ever changing environments. It also opens up space for ecumenical cooperation and appreciation as our individual 'churches' are more appropriately framed as historically conditioned, contextual expressions of the cosmic Mission of God (Love 2013b). We can say that the only mark of a Missional Church which is 'absolute' is an ongoing discernment and participation in the Mission of God. The form, structure and practices of particular communities are relative and derived from this participation (Barret et al. 2004:x).

Rather than outline models or how-to lists, authors have preferred to speak of 'shifts in thinking' (Stetzer \& Putnam 2006:48), 'postures' (Huckins \& Yackley 2012:29-131) or 'patterns' (Barrett et al. 2004:xi) as a more appropriate way to honour the contextual and localised nature of Missional Communities. This language is more representative of an understanding of missional as 'faithful attentiveness to the Spirit's presence and to the world that God so loves' (Roxburgh 2011:149) over and against a dominant culture of models and how-to lists.

In summary, Missional Communities are concrete expressions of a missional ecclesiology animated by the Spirit and a missional imagination that seeks to faithfully discern the missio Dei in a concrete time and place. 


\section{Communal vocation discernment as a core practice of Missional Communities}

If Missional Communities are communities that seek to participate in the missio Dei, we are forced to ask how do they go about discerning specific, local and contextual ways in which they should participate (Niemandt 2010:411; Niemandt 2012:6)? How can this participation in the missio Dei be conceived of within the life of a community of faith (Hahn 2011:145)? How does the missio Dei give birth to the missio ecclesiae (Bosch 1991:370)? Clearly this is a very important, if not central, question that Missional Communities must wrestle with. It is for this reason that vocation discernment not only emerges as a significant theme in the literature (cf. Barret 2004:33-58; Hunsberger 2004:33; Hendriks 2007:1012; Niemandt 2010:409; Roxburgh 2011; Van Gelder 2007a:103; Zscheile 2012:13), but is seen as at 'the heart of missional church practice' (Van Gelder \& Zscheile 2011:130; cf. Niemandt 2012:2). For the church to 'understand itself to be missional ("sent") is to discern its vocation' (Barret et al. 2004:35; [authors' emphasis]). Van Gelder (2007a) summarises this discussion as follows:

\begin{abstract}
A missional ecclesiology understands congregations as being the creation of the Spirit. As communities are created by the Spirit, so also congregations seek to be led by the Spirit. They do this by engaging in some form of discernment process in order to understand their purpose (mission), and how they are being called through this purpose to participate in God's mission in the world ... (p. 107)
\end{abstract}

It is for these and other reasons that Barret et al. (2004:33) identified 'discerning missional vocation' as the first of eight 'patterns' that emerged from the extensive study they conducted of nine Missional Communities. Barret et al. (2004) understand discerning missional vocation as follows:

The congregation is discovering together the missional vocation of the community. It is beginning to redefine 'success' and 'vitality' in terms of faithfulness to God's calling and sending. It is seeking to discern God's specific missional vocation (its 'charisms') for the entire community and for all of its members. (p. 33)

It is worth noting a couple of things in this understanding of discerning missional vocation. Firstly, it is the congregation or community who is doing the discerning together. It is not restricted to the clergy or a few elites but should include the whole community of faith. Secondly, Missional Communities' primary criterion for self-evaluation is that of faithfulness to a God-given vocation (Hunsberger 2004:36-37), which has been communally discerned. A Missional Community seeks above all to be faithful to God's calling (Van Gelder 2007a:103) and sending in a specific place, whether that means growth and public success or whether it means a quiet and unnoticed presence. This truth is very liberating in a culture oppressed by the tyranny of growth and success. Lastly, a Missional Community is seeking to discern its vocation by seeking to identify its charism or unique contribution (Van Gelder 2007a:103) both as a community and for its individual members, in the service of the neighbourhood. Dietterich offers a helpful descriptor of this reality by calling Missional Communities 'pneumocratic', as opposed to egalitarian or democratic (Barrett et al. 2004:174). They are communities that discern the rule and prompting of the Holy Spirit in their midst and context.

This concludes our contention that communal vocation discernment is a core practice of a Missional Community as they seek a located faithfulness to God's cosmic Mission. The remainder of this article will explore the practice of communal discernment and decision making in the Quaker Meeting for Worship in which Business is Conducted ${ }^{4}$, followed by a reflection on what might be usefully appropriated and integrated from the Quakers into Missional Communities' practice of communal vocation discernment.

\section{The Quakers and communal discernment}

For Quakers the first act of the community of faith, like Missional Communities, is discernment. Eden Grace (2000) echoes the convictions and experiences of George Fox $^{5}$ in her summary of Quaker theology and spiritual experience; she identifies three theological themes that inform Quaker spirituality and practice in general and communal discernment and decision making in particular. These theological themes are the inner light of Christ that is given to all in some measure, Christ will teach us himself and unity with one another is a mark of the Divine work in the world.

Believing that 'the inner light of Christ is given to all in some measure' and that 'Christ will teach us himself' necessarily leads Quakers to believe that on issues of communal discernment and decision making there should be unity. There is much to be gleaned for Missional Communities from how Quakers talk about and cultivate unity in their communal discernment. When Quakers say that unity is the goal of communal discernment and decision making, what do they mean? Do they mean unanimity or consensus or do they mean something else? Sheeran (1996:63) believes that part of the difficulty in describing the goal of Quaker discernment and decision making is that 'no conventional term adequately expresses the phenomenon of decisional agreement in a Quaker meeting'. Quakers who recognise the difficulties in speaking of the goal of communal discernment as unanimity prefer to speak of consensus underscoring that:

[T] he bulk of those present agree even if one or two objectors remain. But this, too, is misleading. Quakers are simply not satisfied to know that ... even the overwhelming majority are in agreement. (Sheeran 1996:63)

4.The primary gathering for Quakers is the Meeting for Worship and is the "root' of the Meeting for Business. In order to better understand the significance and practice of the Meeting for Business one must understand the meeting for Worship (cf. Love 2013a:35-36)

5.For a brief treatment of the spiritual experiences that shaped the founder of the Quaker's, George Fox, see Love (2013a:35). 
Whilst contemporary Quakers use the term unity to describe the goal of communal discernment, early Quaker's used the term 'concord' (Sheeran 1996:63) which can be defined as, 'a simultaneous occurrence of two or more musical tones that produces an impression of agreeableness or resolution on a listener' (Merriam-Webster n.d.). This idea is a very helpful way to distinguish Quaker unity from unanimity or consensus. Rather than everyone being a 'single note' Quakers desire people who are 'different notes' to be harmonised into a fuller and more vibrant 'chord' or concord. Unlike in a political gathering in which it is often desirable to have a clear 'winner' and 'loser' the goal for Quakers is 'for all to succeed in a common goal—attending, discerning, and minding the will of the present Christ' (Anderson n.d.:30).

It is not only this nuanced understanding of unity which the Quakers have to offer to Missional Communities but also the practice of how they go about cultivating this unity. We shall focus on the Quaker Meeting for Worship in which Business is Conducted (Sheeran 1996:4-7) in order to appropriate a Quaker spirituality and practice of communal discernment and decision-making. These insights will open up a dialogue with communal vocation discernment in Missional Communities, as we consider points of convergence, divergence and challenge offered by the Quakers in the conclusion. To appropriate Quaker communal decisionmaking adequately one must understand that the process is not simply about making a decision or reaching unity for the sake of it but rather:

$[T]$ he goal is coming to unity around a common sense of Christ's leading, and as with any process of corporate spiritual discernment, such happens most powerfully and effectively within a gathered meeting for worship. (Anderson n.d.:28; [authors' emphasis])

It is for this reason that the communal decision making space in the Quaker community is known as the Meeting for Worship in which Business is Conducted. This highlights the weight with which Quakers treat communal discernment and decision making.

\section{How unity is reached in The Meeting for Business}

Sheeran (1996:63-65) sees five basic and dynamic movements on the discernment journey towards unity, namely:

- the opening silence

- the preliminary discussion

- the serious discussion

- the dissent from the proposed minute

- unity.

Before we look at the five movements let us consider the critical role of the Clerk (or facilitator) in communal discernment.

In terms of the role of the Clerk, Grace (2003) gives an excellent summation of the role and responsibility of the Clerk: ${ }^{6}$

6.See Steere's outline of the responsibilities of the Clerk (in Sheeran 1996:91).
The Meeting is served by a Presiding Clerk ... Friends are appointed for a limited time, and these roles are widely shared among the membership. The Clerks have no formal authority of their own and cannot speak for the Meeting. Their task is to focus and enable the discernment of the Meeting by laying business before it in an orderly way, managing the pace and discipline of the discussion, listening for the Sense of the Meeting to emerge, restating that Sense in clear language and asking for approval, and recording the business in written minutes. The Clerks develop the agenda and discern whether an issue is ripe for consideration by the Meeting or needs further seasoning by a committee.

The Meeting for Business opens with silence or prayer (Anderson n.d.:29), which is an opportunity to 'open oneself to the guiding hands of the Holy Spirit' (Birkel 2004:69). This is an important opportunity to set aside any positions or strategies for persuasion that one has developed regarding the issues at hand. It is an opportunity to avail oneself to the guidance and leadership of Christ rather than our own narrow (and often divisive agendas).

The silence is a reminder to the community that first and foremost this is a meeting for worship and that it is God's will that the community seeks.

The preliminary discussion follows the initial presentation of both the problem and some possible solutions by the Clerk (Sheeran 1996:64). This is normally followed by a time for questions, tentative alternatives and general brainstorming around the proposal. This part of the process is not too serious or committal but more about 'feeling the issue out'. As important issues and concerns are raised throughout the process, the Clerk will often 'introduce times of prayer or quiet during the meeting' (Anderson n.d.:30) to aid in reflection, to centre the group and remind it of the One who is being sought.

As people begin to speak gradually a momentum will build. Speakers will follow-up what others have said, some will say 'yes I agree with so-and-so'. The challenge for the Clerk at this point is twofold. Firstly, the conversation could be taking several directions or indeed no direction at all. Secondly, the Clerk needs to 'gather input from all sides of the issue ... to be sure that alternative perspectives are a direct part of the deliberations' (Anderson n.d.:30). The issue must continue to be discussed until either a dominant position begins to emerge or there is agreement that a decision cannot be made now (Grace n.d.:51; Sheeran 1996:64). If a dominant position is emerging then the Clerk will propose a tentative Sense of the Meeting. The Sense of the Meeting is a summary of where the group feels a 'oneness of accord on both the identification of the issues to be addressed and what might be 'the mind of Christ' in addressing those issues' (Anderson n.d.:42). Once the Clerk proposes a Sense of the Meeting regarding the particular issue then everyone is expected to answer two questions (Sheeran 1996:64). Firstly, does the facilitator's Sense of the Meeting capture the essence of the conversation? If not then conversation continues until there is a generally 
agreed upon 'Sense' of what the group is saying. If the Clerk does propose a 'Sense' and it is accepted by the community then it is minuted and 'becomes authoritative ... minutes and minute-taking are crucial to the process, and are seen as a weighty spiritual practice rather than a clerical function' (Grace 2000). If a proposed sense does capture what the group is saying but an individual participant cannot unite (read agree) with the 'Sense' then that person is expected to express dissent.

If an individual cannot agree with the Sense of the Meeting and dissents from it, 'it may be taken as a sign that the Divine will has not quite been grasped' (Grace 2000). As a Quaker you have three ways to express dissent (Sheeran 1996:65-70):

- Type 1: 'I disagree but do not wish to stand in the way'.

- Type 2: 'Please minute me as opposed'.

- Type 3: 'I am unable to unite with this proposal'.

On a continuum, from 'weak' dissent to 'strong' dissent, Type 1 would be the weakest form of dissent and Type 3 would be the strongest.

This first and most common type of dissent expressed in meetings is when a member has a genuine concern that they feel needs to be expressed but they do not feel that it is sufficient to prevent the community from moving forward on the decision. In this case the person would say something like, 'I disagree but do not wish to stand in the way'. This person feels that they cannot agree wholeheartedly with the 'Sense' but does not feel that their objection is strong enough to prevent the community from moving forward with the decision. There is an interesting dynamic that unfolds in taking this position. The dissenter is able to maintain integrity (Sheeran 1996:66-67) by publicly expressing doubt or disagreement with the community but at the same time feels compelled to carry out the decision of the community because they are aware that if they felt stronger about it they could express a stronger form of dissent (explored below). This insight alone could prevent so much conflict in communities as it allows and indeed encourages a platform for people to express dissent but also gives weight to the wisdom of the community and the Christian commitment to unity (Jn 17).

The second type of dissent which is much less common, and so is a much stronger form of dissent is to request to be recorded in the minutes as opposed to the decision. When this happens, the objector, 'wishes that the minute expressing the sense of the meeting should note his or her disagreement' (Sheeran 1996:69; cf. Grace n.d.:52). Again like the type of dissent discussed above this type does not prevent the community from moving ahead with the decision. Rather it communicates to the immediate and wider community that this decision needs to be carried out with sensitivity, caution and awareness since some members of the decision making community have strong reservations. This form of dissent is particularly helpful with contentious or complex issues as it communicates to the wider community the complexity of the decision. It communicates to the immediate and wider community that it was not a decision taken lightly or with a lack of awareness of the possible consequences the decision could have. In a polarised world filled with difficult and complex challenges this practice could create some space for maintaining unity in the diversity that characterises so much of contemporary South African civil and religious life.

The third type of dissent and indeed the strongest is expressed when someone says something like, 'I am unable to unite with this proposal'. This type of dissent is appropriate when a person feels so strongly about the dissent that they are unwilling to stand aside or to be minuted as opposed. Any dissent, but particularly this kind, 'may be taken as a sign that the Divine will has not quite been grasped and may indicate the Meeting has not truly listened to God's prompting' (Grace 2000). In this case, the meeting cannot move ahead on the decision and it is often delayed until the next meeting to reach unity. Often if there is a pressing deadline or the dissent seems unnecessary, 'the clerk or another friend may appeal to the objector to withdraw the objection or to consent to being minuted as opposed' (Sheeran 1996:70). If, however, the individual's conscience does not allow them to 'stand aside' then during the break between meetings all parties take time to re-evaluate their position. The Clerk and respected members of the community might seek to 'labour' with the objector in order to understand the root of the objection (Sheeran 1996:70) in the hope of 'coming to truer understanding of God's will' (Grace 2000). According to Sheeran (1996:70), 'at the meeting that follows, very often agreement is possible' because often times the root of the persons objection will merely require a nonessential change in the proposal to acknowledge their objection or 'he or she is confident that the trusted members of the meeting have understood his or her point of view and having thought it through conscientiously, still do not agree' (Sheeran 1996:70). This then allows the community to continue with the decision. On more rare occasions the person can continue to object and the same process described above plays itself out over a period of time but with each delay social pressure does escalate for the person to stand aside.

\section{Quaker enrichment of communal vocation discernment in Missional Communities}

What follows are some of the pertinent insights and practices that Quakers can offer for the informing and transforming of communal vocation discernment in Missional Communities. Before we consider these insights and practices that are potentially helpful for Missional Communities, let us consider the points of convergence and the points of divergence between these two communities' practice of communal discernment.

\section{Points of convergence}

The points of convergence between these two communities include the primacy of discernment and the primacy of community. 


\section{The primacy of discernment}

The first point of convergence between Missional Communities and Quakers is the primacy of discernment in birthing and sustaining these communities. Missional Communities see themselves to be, through discernment, communities led by the Spirit. They are communities that unequivocally see discernment as the first act of mission and it is this discernment of the Mission that gives birth to the localised community and its contextual Mission. There is much in this description that would resonate with Quakers. For Quakers their spirituality is a relentless 'waiting on the Lord' (Anderson n.d.:26) from which all else flows, including communal decision making. There is a sense in which discernment is the tradition of the Quakers. This sentiment is equally true for Missional Communities. The expectation that the Spirit, as an active participant in the conversation, will lead us in our vocation and decision making is key to both communities. Both of these communities do not simply practice discernment as part of their life but indeed are communities of discernment.

\section{The primacy of community}

The second point of convergence, which is intimately connected to the primacy of discernment, is the primacy of community. Both Missional Communities and Quakers see the community as the primary place of discernment. The vocation of the Missional Community is not discerned by the clergy on behalf of the community but rather is discerned by the community. Leaders (who might or might not be clergy) are those who create the space and facilitate the process of discernment for the Missional Community. They exist in an interdependent relationship with the rest of the community under the guidance and leading of the Spirit. The nuanced and multifaceted understanding of the community's vocation requires input and listening from the diversity of members that comprise the community. The vocation shapes the common identity of the community and the community is the site in which this vocation is discerned. For Quakers the primacy of community acts as a counter-balance to individual 'leadings' that often conflict in communal life and decision making. The unity of the community is taken as a sign of the Divine work in the world as well as a sign of the Divine will regarding particular decisions. The community also adds texture, nuance and weight to decisions as different perspectives and concerns are harmonised into a fuller and more vibrant unity or concord. The communal dimension of discernment is inherent to both these communities practice of it.

\section{Points of divergence}

A significant point of divergence could be seen as an oversimplification but is worth highlighting. The point of divergence is around the 'locale' of God. Of course both communities would believe (as all Christians do) that God is in some sense 'everywhere' but the distinctive nuance is that Missional Communities highlight God's work and presence 'out there' in the world, in the neighbourhood, beyond the community of faith. Roxburgh (2011:162) captures this dynamic when he exhorts us to 'get out of our churches and re-enter our neighborhoods and communities [this] ... is where we will discern God's future'. A critical part of a Missional Community's communal discernment is about finding God in the neighbourhood and broader community. This emphasis does not mean that the community does not gather together to discern. It means that outside of meaningful connection with the broader community and an understanding of the identity (i.e. socially, culturally, geographically and historically) of the place they are located in they will not be able to discern their local and contextual participation in the missio Dei. This theme is well developed in the missional movement (cf. Hunsberger 2004:38; Van Gelder 2007a:103) and truly is a gift to the church and possibly to Quakers. It would seem that for Quakers the primary (though obviously not exclusive) locale of God is in the midst of the gathered faith community. Sheeran (1996:82) summarises this sentiment by saying, 'Quakerism builds all on the experience of the gathered meeting'. This would be a significant point of divergence between these two communities that would influence the practice of how they go about communal discernment.

\section{Appropriation of Quaker practice for vocation discernment in Missional Communities}

Let us now consider communal discernment as worship and unity (with space for dissent) as two practices that can be appropriated by Missional Communities in their own practice of vocation discernment.

\section{Communal discernment as worship}

Quakers highlight the truth of communal discernment as worship with such clarity that Missional Communities would do well to take notice. In naming their communal discernment space as the Meeting for Worship in which Business is Conducted, they are reminding themselves (and the rest of the church) that seeking participation in the Divine life and will is an act of worship. From mundane day-to-day decisions to questions of communal vocation and everything in between, communal discernment is an act of worship. The Quaker practice of communal discernment intentionally makes place for God to be an active participant in the discernment process. As Missional Communities we must remember that our desire to become integral participants in our neighbourhood, listening to and serving our neighbours as well as the more 'formal' parts of vocation discernment (i.e. studies, interviews, analysis, processes, reflection, etc.) are not just good things to do but are expressions of our desire to participate in the Divine life as an act of worship. Of course, this is not an entirely new insight for Missional Communities (Van Gelder \& Zscheile 2011:151-152) but the author finds the Quaker language and practice a particularly refreshing take on this theme. How can Missional Communities' language be shaped and formed to remind us that both the formal and informal parts of discerning our communal vocation are acts of worship? As we gather to discern what we have heard in our neighbourhoods and what our role in them might be, 
are we aware that we are in a Meeting for Worship in which our Communal Vocation is being Discerned?

Another helpful way in which Quakers remind us of the worshipful nature of communal decision making and vocation discernment is through their strategic use of silence. The opening and closing silence reminds us that whether it be communal vocation discernment or decision making these are acts of worship. The use of silence at critical points in a discussion or during an impasse or at times of conflict in communal discernment reminds the community that it is not power or the dominance of our own view but rather it is participation in the Divine life that we seek. Quaker's seem strong in creating space for the Spirit to be an active participant in the discerning process.

\section{Unity (with space for dissent) as the path of communal vocation discernment}

The second area to be appropriated for Missional Communities is the Quaker emphasis on unity as a sign of Divine work in the world. As it relates to Missional Communities, the Quaker argument for unity as a sign of Divine work might be restated as such. If the local Missional Community is seeking to discern the leading of the Spirit in its communal vocation there will be unity. The Spirit is not divided and so the nearer we come to the Spirit, the nearer we will come to one another. This nearness to one another (or unity) we take as a mark of the Spirit's work in our world and in the life of the community. This insight like the one above is not entirely novel insight but the bold and striking way in which Quakers practice this commitment is very useful for Missional Communities. Framing this as a space of worship and practicing unity or concord as the telos of discerning communal vocation are critical if Missional Communities are to reach the agreement that Quakers so brilliantly embody. When unity in discerning communal vocation is actively pursued out of fidelity to the Spirit, Missional Communities have the potential of reaping all the benefits that Birkel (2004:69) believes Quakers enjoy including high communal ownership, a deeper sense of community and an absence of minority factions. Of course the true genius of Quaker practice is their deep commitment to unity whilst at the same time creating space for dissent. Missional Communities' practice of communal vocation discernment can be strengthened through integrating this nuanced and rich practice of dissent. Without the 'release valve' that these categories of dissent allow one wonders how much genuine 'agreement' will be reached in Missional Communities.

After all this we now return to our original question. Is the Quaker practice of communal discernment a suitable model for communal vocation discernment in Missional Communities? Yes and no. It is not suitable in so far as it does not hold explicit commitments to being rooted in and connected to the local neighbourhood as a critical source in vocation discernment. For Missional Communities this commitment to location must be at the forefront of vocation discernment and should be adequately reflected in the language and practice of the community. The Quaker model is not only suitable but indeed critical in so far as it continually reminds a Missional Community that communal discernment is first and foremost an act of worship. This commitment to communal discernment as worship is further enhanced through the helpful naming of the communal discernment space as a worship space and the Quaker's proficiency in using silence at an impasse, conflict or critical point of discernment. The Quaker practice of unity (and dissent) is also an extremely insightful appropriation for Missional Communities' own communal discernment. If a Missional Community's desire is for people to feel that they belong within the communally discerned vocation of the community then there must be unity in this discernment and if they want their community members to realise their own agency and responsibility in the communally discerned vocation there must be space to dissent. A unity without space for dissent quickly degenerates into coercion and uniformity. Unity, agency and responsibility are all critical elements for the flourishing of Missional Communities and Quaker language and practice around these themes seem to be a tremendous gift in this regard (Love 2013b).

\section{Acknowledgements Competing interests}

The authors declare that they have no financial or personal relationship(s) that may have inappropriately influenced them in writing this article.

\section{Authors' contributions}

C.R.L. (University of Pretoria) did the Research, conceptualisation and execution of this article. J.P.N. (University of Pretoria) was the study leader and project supervisor; he provided overall direction and assisted with conceptualisation and resources.

\section{References}

Anderson, P. n.d., 'The meeting for worship in which business is conducted - Quaker decision-making process as a factor of spiritual discernment', in George Fox University, viewed 05 March 2012, from http://www.georgefox.edu/discernment/ QRTAnderson.pdf

Balia, D. \& Kim, K. (eds.), 2010, Witnessing to Christ today, Regnum Books International, Oxford. (Regnum Edinburgh 2010 Series).

Barrett, L.Y., Guder, D.L., Hobbs, W.C., Hunsberger, G.R., Stutzman, L.L., Van Kooten, J. et al. (eds.), 2004, Treasures in jars of clay: Patterns in missional faithfulness, William B. Eerdmans Publishing Company, Grand Rapids.

Birkel, M., 2004, Silence and witness: The Quaker tradition, Longman \& Todd, Bath.

Bosch, D., 1991, Transforming mission: Paradigm shifts in theology of mission, Maryknoll, Orbis.

Connor, B.T., 2011, Practicing witness: A missional vision of Christian practises, William B. Eerdmans Publishing Company, Grand Rapids.

Downey, M., 1997, Understanding Christian Spirituality, Paulist Press, New York.

Grace, E., 2000, An introduction to Quaker business practice, viewed 05 March 2012, from http://www.edengrace.org/quakerbusiness.html

Grace, E., 2003, Guided by the mind of Christ: Yearning for a new spirituality of Church governance, viewed 05 March 2012, from http://www.edengrace.org/guided. html

Grace, E. n.d., Voting not to vote: Toward consensus in the WCC, viewed 05 March 2012, from http://www.georgefox.edu/discernment/QRTGrace.pdf

Guder, C. (ed.), 1998, Missional church: A vision for the sending of the Church in North America, William B. Eerdmans Publishing Company, Grand Rapids.

Guder, D., 2000, The continuing conversion of the Church, William B. Eerdmans Publishing Company, Grand Rapids. 
Guder, D., 2009, 'Missio Dei: Integrating theological formation for apostolic vocation', Missiology: An International Review 37(1), 65.

Hahn, D., 2011, 'Congregational discerning as Divine action in conversation', in D.J. Zscheile (ed.), Cultivating sent communities: Missional spiritual formation, pp. 145-166, William B. Eerdmans Publishing Company, Grand Rapids.

Hailey, J., 2008, Ubuntu: A literature review, The Tutu Foundation, London.

Hendriks, H.J., 2007, 'Missional theology and social development', HTS Teologiese Studies/Theological Studies 63(3), 999-1016. http://dx.doi.org/10.4102/hts. v63i3.244

Huckins, J. \& Yackley, R., 2012, Thin places: 6 Postures for creating and practicing Missional Community, The House Studio, Kansas City.

Hunsberger, G., 2004, 'Discerning missional vocation', in L. Barret (ed.), Treasures in clay jars: Patterns in missional faithfulness, pp. 33-58, William B. Eerdmans in clay jars: Patterns in missional
Publishing Company, Grand Rapids.

Kim, K., 2009, Joining in with the Spirit: Connecting world church and local Mission, Epworth, London.

Love, C., 2013a, Missional communities: The vocational discernment question in dialogue with Quaker communal discernment, St. Augustine College, Pretoria.

Love, C., 2013b, Research paper: Conclusion (Part 5 of 6), Curis Among Friends (Blog), viewed 10 January 2009, http://curtisamongfriends.com/home/2013/06/ research-paper-conclusion-part-5-of-6/?

Love, M., 2010, 'Missio Dei, trinitarian theology, and the quest for a post-colonial missiology', Missio Dei 1, 37-51.

Macllvaine, R., 2009, Selected case studies in how senior leaders cultivate missional change in contemporary churches, Dallas Theological Seminary, Dallas.

McKinzie, G., 2010, 'An abbreviated introduction to the concept of Missio Dei', Missio Dei 1, 9-20.

Merriam-Webster, n.d., s.v. 'concord', viewed from http://www.merriam-webster. com/dictionary/concord
Newbigin, L., 1987, Mission Christ's Way, World Council of Churches, Geneva.

Niemandt, C.J., 2010, 'Five years of Missional Church: Reflections on missional ecclesiology', Missionalia 38(3), 397-412.

Niemandt, C.J., 2012, 'Trends in missional ecclesiology', HTS Teologiese Studies/ Theological Studies 68(1), 1-9. http://dx.doi.org/10.4102/hts.v68i1.1198

Roxburgh, A.J. \& Boren, S., 2009, Introducing the Missional Church: What it is, why it matters, how to become one, Baker Books, Grand Rapids.

Roxburgh, A.J., 2011, Missional: Joining God in the neighborhood, Baker Books, Grand Rapids.

Sheeran, M.J., 1996, Beyond majority rule: Voteless decisions in the Religious Society of Friends, Yearly Meeting of Religious Society of Friends, Philadelphia.

Shenk, W.R., 1995, Write the vision: The Church renewed, Trinity Press International, Harrisburg.

Stetzer, E. \& Putnam, D., 2006, Breaking the missional code: Your church can become a missionary in your community, Broadman \& Holdman, Nashville.

Van Gelder, C., 2007a, The ministry of the Missional Church, Baker Books, Grand Rapids.

Van Gelder, C. (ed.) 2007b, The Missional Church in context: Helping congregations develop contextual ministry, William B. Eerdmans Publishing Company, Grand Rapids.

Van Gelder, C. \& Zscheile, D.J., 2011, The Missional Church in perspective: Mapping trends and shaping the conversation, Baker Academic, Grand Rapids.

World Communion of Reformed Churches (WCRC), 2010, Proceedings of the Uniting General Council of the World Communion of Reformed Churches, Grand Rapids, Michigan, USA, June 18-28, 2010, pp. 1-331.

Wright, C.H., 2006, The Mission of God: Unlocking the Bible's grand narrative, IVP Academic, Downers Grove.

Zscheile, D.J., 2012, Cultivating sent communities: Missional spiritual formation, William B. Eerdmans Publishing Company, Grand Rapids. 